\title{
Preservice teachers' twenty first century learning skills: Three different majors of study
}

\author{
Prasart Nuangchalerm * \\ Faculty of Education, Mahasarakham University, Mahasarkahm, Thailand
}

\section{A R T I C L E I N F O}

\section{Article history:}

Received 15 March 2017

Received in revised form

14 June 2017

Accepted 15 June 2017

\section{Keywords:}

Learning skills

Preservice teacher

Instruction

Perception

\begin{abstract}
A B S T R A C T
Twenty century learning skills are important to learners for living in today and tomorrow. This study aimed to study and compare preservice teachers' $21^{\text {st }}$ century learning skills by different majors of study. Panel participants were preservice teachers, 38 of general science and 20 of English bachelor program who enrolled curriculum design and development course, 35 of social studies bachelor program who enrolled classroom management and learning environment course. Data were collected by preservice teachers' $21^{\text {st }}$ century learning skills questionnaire. Mean, standard deviation, and One Way ANOVA are employed for data analysis. Findings indicated that they had $21^{\text {st }}$ century learning skills at high level. Program of study had no differences, but the element of skills had significantly differences at .05 levels of statistics.
\end{abstract}

(C) 2017 The Authors. Published by IASE. This is an open access article under the CC BY-NC-ND license (http://creativecommons.org/licenses/by-nc-nd/4.0/).

\section{Introduction}

The paradigm of education movement in Thailand is now currently changed through the mainstream of sociocultural adaptation. It is differ from those previous educational activities, the $21^{\text {st }}$ century learning is currently occurred and substitutions to our society, learning to be adapted from passive to active approach (Sherrill, 1999). However, these changes influenced to program for preparing effective teachers. Due to it is now calling to produce professional teachers in both thinking and practices. While learning behavior and characteristics of most students seem to be advanced.

Preservice teachers will be qualified before go to school workplace, be an in-service teacher who can change our society in the future, they have to gain their professional experiences as the requirements of Teacher Council of Thailand (TCT, 2013) determined. Thus, teacher preparation program considered a critical production for preparing themselves to face with tomorrow classroom. They are key agent to change instructional practices and curriculum development for changing period of time. They have to understand about and of necessary skills for promotion students' achievement, life skill, career skills, and learning skills.

\section{* Corresponding Author.}

Email Address: prasart.n@msu.ac.th

https://doi.org/10.21833/ijaas.2017.07.018

2313-626X/C) 2017 The Authors. Published by IASE.

This is an open access article under the CC BY-NC-ND license

(http://creativecommons.org/licenses/by-nc-nd/4.0/)
The $21^{\text {st }}$ century learning skills are widely distributed in all education level, that meant all students should have necessary learning tools. Also, teachers must be known and skilled before-during implementing curriculum. This approach is propagated by Thailand Qualification Framework in Higher Education (TQF-HEd). In addition, TCT regulated $21^{\text {st }}$ century learning skills through professional standards. So that, teacher preparation program needs to embed suitable approach to curriculum and instructional practices by different methods (Prachagool et al., 2016).

Faculty of Education, Mahasarakham University launched teacher preparation program for five-year program study since 2005. Teacher preparation program concentrate on shaping professional development and creating of what good teacher should be (Darling-Hammond, 2006). These are key agent to transform students' learning to have knowledge, skills, and desirable attributes which society needs. Teacher education needs much more effectiveness that the requirements of education standards determined (Prachagool et al., 2016). They have to take 4-year courses in university and 1-year practicum in school (TCT, 2013). These are important for preparing our teachers in the future as well as necessary learning and career skills in age of the $21^{\text {st }}$ century. They should be and should have as well as transmit or adapt their skills to all children.

The $21^{\text {st }}$ century learning skills is initiated to education 4.0 for preparing our children to face with uncertainty and changing world. These learning skills are invited to teacher preparation program, provided approach to design thinking for future 
classroom. Educational policy pushed in various ways of method, but the educational practices are less compiled. They can move up or promote learning skills to our children. So, this study needs to know perception of preservice teachers in $21^{\text {st }}$ century learning skills. If teachers have no $21^{\text {st }}$ century learning skills, it can predict that students may be less in such skills. The study aims to explore $21^{\text {st }}$ century learning skills of preservice teachers. Result will help educator's aware curriculum and instructional practices for teacher preparation program.

The goal of study needs to know level of $21^{\text {st }}$ century learning skills of preservice teachers in three majors. Also, to compare element of learning skills in which they have by differences major. Science and non-science preservice teachers are defined. Perception about $21^{\text {st }}$ century learning skills are explored and compared.

\section{Methods}

\subsection{Participants}

The study investigated perception on $21^{\text {st }}$ century learning skills of preservice teachers in different major of study. Third year, 38 of general science and 20 of English bachelor program who enrolled curriculum design and development course majors. Fourth year, 35 of social studies bachelor program, who enrolled classroom management and learning environment course participated. These courses were core subject of teacher profession in the first semester, academic year 2016. Each course, preservice teachers will be learnt how to incorporate $21^{\text {st }}$ century learning skills into curriculum and instructional practices.

\subsection{Procedural study}

The study of two courses, three groups of major of study were invited to preservice teachers, the $21^{\text {st }}$ century learning and how preservice teachers should be aware, embedded this approach to their future classroom. They were asked the $21^{\text {st }}$ century learning skills with 25 -item in 5 elements. The questionnaire was rated from 1 to 5 by meaning of lowest, low, medium, high, and highest, which questionnaire was developed from Siriluk et al. (2014). Then let participants to express their perception. Data were collected by hand in hand. Later, data were analyzed by statistical package to the level of their perception in terms of mean, standard deviation.

The level of perception was considered with Likert's five-point rating scale. Each respondent was asked to rate each item on some response scale. They could rate each item on a 1-5 response scale where; 1 = lowest, 2 = low, $3=$ medium, $4=$ high and $5=$ highest. Researcher checked the completeness of the data and then obtained data from responses to the questionnaire. Data were recorded; statistic values were calculated and interpreted by using the criteria as Table 1.

Table 1: Study criteria

\begin{tabular}{cc}
\hline Mean & Interpretation \\
\hline $4.51-5.00$ & Highest \\
$3.51-4.50$ & High \\
$2.51-3.50$ & Medium \\
$1.51-2.50$ & Low \\
$1.00-1.50$ & Lowest \\
\hline
\end{tabular}

The perceptions were calculated, to meet the purpose of the study, data were described in terms of level of perception about $21^{\text {st }}$ century learning skills. Also, to compare differences by major of study, and its element were explored. One Way ANOVA was conducted for testing mean differences and then data and its results were shown in terms of mean score comparison. In addition, qualitative data were explored in terms of interviewing. Mean score which are 3 majors of study express their perception to learning.

\section{Results and discussion}

\subsection{Level of $21^{\text {st }}$ century learning skills}

Twenty first century learning skills of preservice teachers in different major found that they had $21^{\text {st }}$ century learning skills at high level. Social study and English majors had high level at all elements, but general science major showed their $21^{\text {st }}$ century learning skills in terms of creativity skills in medium level (Table 2).

Most of elements, preservice teachers should have showing in high level, but creativity in general science major had medium level. Other elements in general science had high level by life and career skill, ICT, medias, information technology skill, communication skill, and critical thinking skill in following. In the same exploration, social study and English showed their level of skills high level by life and career skill, ICT, medias, information technology skill, communication skill, critical thinking skill, and creativity in following (Fig. 1). The professional development can be used pedagogical content knowledge for providing an effectively instructed to teachers. It enhances their competency in curriculum design and learning management as well (Nuangchalerm, 2012).

They had high mean score in life and career skills, ICT, medias, information technology skills for the first second skills priority. New era of learning employed ICT to classrooms which engage teacherstudent interaction, response to their real need, answer nature of young learners (Archambault et al., 2010). They are rapidly learned with new thing and interest multimedia because it make them happy than those passive learning (Lambert and Gong, 2010).

Preservice teachers employed information and communication technology, social networking, online learning, and instructional multimedia as instructional tools. They are able to provide more 
feedback to one another as well as communicate

2010). more efficiently and effectively (Archambault et al.,

Table 2: Level of learning skills of preservice teachers

\begin{tabular}{cccc}
\hline \multirow{2}{*}{ Learning skills } & \multicolumn{4}{c}{ General Science } \\
\cline { 2 - 5 } & Mn & SD & Level of skills \\
\hline Creativity & 3.34 & 0.73 & Medium \\
Critical Thinking & 3.61 & 0.63 & High \\
Communication & 3.87 & 0.66 & High \\
ICT, Medias, Information Technology & 3.78 & 0.70 & High \\
Mean score & 4.14 & 0.63 & High \\
& 3.81 & 0.72 & High \\
\cline { 2 - 5 } Creativity & \multicolumn{4}{c}{ Social Study } \\
\cline { 2 - 4 } Critical Thinking & 3.52 & 0.75 & High \\
Communication & 3.69 & 0.72 & High \\
Life and Career & 3.00 & 0.74 & High \\
Mean score & 3.82 & 0.69 & High \\
& 3.10 & 0.70 & High \\
ICT, Medias, Information Technology & 3.87 & 0.75 & High \\
\cline { 2 - 4 } Creativity & \multicolumn{3}{c}{ English } \\
\cline { 2 - 4 } Critical Thinking & 3.63 & 0.74 & High \\
Communication & 3.61 & 0.75 & High \\
Life and Career & 3.83 & 0.73 & High \\
Mean score & 3.79 & 0.67 & High \\
& 4.28 & 0.71 & High \\
ICT, Medias, Information Technology & 3.88 & 0.76 & High \\
\hline
\end{tabular}

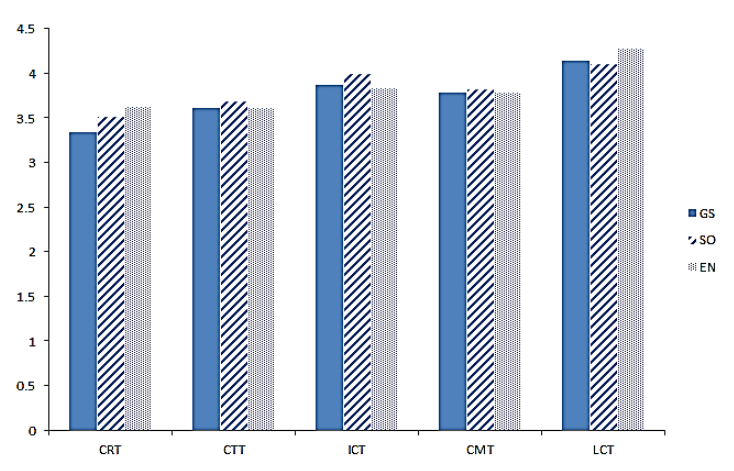

Fig. 1: Twenty-first century learning of preservice teachers by different majors

Because these allowed them to the greater open access and distance communication, that is, useful implication for students with receiving in more immediate and ongoing feedback through their use. These skills need to integrate in school and workplace of education (Gut, 2011). They have to bring crucial skills into lessons which created by preservice and inservice teachers. Because the changing world need classroom activities and its environments that invite inspiration and motivation as well as necessary skills are implemented. Twenty first century learning skills help preservice teachers adapt themselves familiar with tools and methods. Häkkinen et al. (2017) reviewed the status of policy frameworks for the $21^{\text {st }}$ century learning skills about current understanding in the field of learning sciences. These skills need to elaborate the processes and strategies for collaborative problem-solving skills. Also, learning skills will be improved if they had critical thinking, critical reflection, communication, and collaboration to use information technologies in creative contexts. Preservice teachers had less anxious about computers and information technology because it is a part of modern life. They believed in the value of using technology by different purposes and methods to enhance teaching and learning as well as their self-efficacy. They became more advanced in their technical skills and knowledge of how to apply these skills in the classroom for promoting lifelong learning (Lambert and Gong, 2010).

\subsection{Comparison of element and major of study}

For comparing the element of $21^{\text {st }}$ century learning skills, each element were investigated and tested by ANOVA. It found that each element had significantly differences at .05 levels of statistics (Table 3).

Five elements of $21^{\text {st }}$ century learning skills had differences- creativity; critical thinking; ICT, medias, information technology; communication; and life and career. That is a finding to bridge the gap between each element for fulfilling through curriculum and teacher preparation program. Content seems to be important for classroom, but less than those necessary skills for life and career in the $21^{\text {st }}$ century.

Table 3: Comparing element of $21^{\text {st }}$ century learning skills

\begin{tabular}{cccccc}
\hline & Sum of Squares & df & Mean Square & F & Sig. \\
\hline Between Groups & 122.980 & 43 & 2.860 & & \\
Within Groups & 28.700 & 31 & .926 & 3.089 & .001 \\
Total & 151.680 & 74 & & & \\
\hline
\end{tabular}

These skills may be shown to preservice teachers by unfamiliarly situations (Mishra and Mehta, 2017). Curriculum for teacher preparation might want to aware and integrate to professional practices in both university and school practicum. Smith and $\mathrm{Hu}$ (2013) reflected the views of teaching and learning 
for $21^{\text {st }}$ century learning. Life and career skills help cultivate the virtues of responsibility, commitment, industry and persistence. In addition, learning and innovation skills promote critical thinking, communication, collaboration and creativity. While information and communication technology are supports and lead preservice teachers to new knowledge and self-directed learning. Program for teacher production needs creativity which is an important survival skill for $21^{\text {st }}$ century. It helps us face challenges in life, adapt and develop ourselves in education, business and life as a whole (Rabi and Masran, 2016).

Major of study was tested; there was no difference among general science, social studies, and English majors (Table 4).

Table 4: Comparing major of study

\begin{tabular}{|c|c|c|c|c|c|}
\hline & Sum of Squares & $\mathrm{df}$ & Mean Square & $\mathrm{F}$ & Sig. \\
\hline Between Groups & 29.000 & 43 & .674 & & \\
\hline Within Groups & 21.000 & 31 & .677 & .996 & .512 \\
\hline Total & 50.000 & 74 & & & \\
\hline
\end{tabular}

The major of study showed that no differences in $21^{\text {st }}$ century learning skills because teacher preparation program was regulated by Thailand Qualification Framework to fulfill students' learning competency. They have to express learning and career skills to meet the requirements of teacher education. Also, Teacher Council of Thailand determined characteristics of preservice teachers to prepare them face with changes in school life. Schooling is to educate the upcoming generation and need more challenges in terms of lifelong learning. All major of study in teacher preparation program concerned and become active participation in creating future society, adaptation teaching and learning in the information-rich digital age (Starkey, 2011). Preservice teachers must to develop themselves as well in all crucial skills by active participation, beliefs, understanding how to apply suitable theories of learning that are relevant to their school practices. Williams et al. (2009) explored preservice teachers used a variety of strategies to learn new innovations well enough to teach or model their use to classmates, that mean it meet the requirements of $21^{\text {st }}$ century learning skills. TCT (2013) examined these expectations in terms of teacher standards; they have to learn content and pedagogy in success by various majors of study. They are strengthened confidence in deeper understanding of content, the usefulness of tools for instructional practices, and abilities to collaborate with technology in their school workplace.

In sum, three mjors of study had $21^{\text {st }}$ century learning skills in high level. It causes the regulation of Teacher Council of Thailand, goal to produce teachers in effectively and efficiently. The regulation introduced all teacher preparation programs to have knowledge, skills, and desirable attributes relevant to professional teachers with $21^{\text {st }}$ century learning skills. Also, Thailand Qualification Framework designed all programs and courses to meet the requirement of quality in education.

\section{Conclusion}

Twenty first century learning skills are necessary for preservice teachers. In terms of creativity; critical thinking; ICT, medias, information technology; communication; and life and career that are crucial skills. Three majors showed in high level of skills which can predict effectiveness and efficiency in teaching and learning. Also, major of study is approved that there are no difference.

\section{References}

Archambault L, Wetzel K, Foulger TS, and Kim Williams M (2010). Professional development 2.0: Transforming teacher education pedagogy with 21st century tools. Journal of Digital Learning in Teacher Education, 27(1): 4-11.

Darling-Hammond L (2006). Constructing 21st-century teacher education. Journal of Teacher Education, 57(3): 300-314.

Gut DM (2011). Integrating 21st century skills into the curriculum. In: Wan G and Gut DM (Eds.), Bringing schools into the 21st Century: 137-157. Springer Science and Business Media, Berlin, Germany.

Häkkinen P, Järvelä S, Mäkitalo-Siegl K, Ahonen A, Näykki P, and Valtonen T (2017). Preparing teacher-students for twentyfirst-century learning practices (PREP 21): A framework for enhancing collaborative problem-solving and strategic learning skills. Teachers and Teaching, 23(1): 25-41.

Lambert J and Gong Y (2010). 21st century paradigms for preservice teacher technology preparation. Computers in the Schools, 27(1): 54-70.

Mishra P and Mehta R (2017). What we educators get wrong about 21st-century learning: results of a survey. Journal of Digital Learning in Teacher Education, 33(1): 6-19.

Nuangchalerm P (2012). Enhancing pedagogical content knowledge in preservice science teachers. Higher Education Studies, 2(2): 66-71.

Prachagool V, Nuangchalerm P, Subramaniam G, and Dostal J (2016). Pedagogical decision making through the lens of teacher preparation program. Journal for the Education of Gifted Young Scientists, 4(1): 41-52.

Rabi NM and Masran MNB (2016). Creativity characteristics in teaching students with learning disabilities among pre-service teacher in UPSI. International Journal of Advanced and Applied Sciences, 3(11): 66-72.

Sherrill JA (1999). Preparing teachers for leadership roles in the 21st century. Theory into Practice, 38(1): 56-61.

Siriluk W, Prachanban P, and Parnichparinchai T (2014). Indicators Development of Student's Skills in the $21^{\text {st }}$ Century. Journal of Education Naresuan University, 16(4): 155-165. Available online at: http://www.tci-thaijo.org/index.php/ edujournal_nu/article/download/21953/18947

Smith J and $\mathrm{Hu}$ R (2013). Rethinking teacher education: Synchronizing eastern and western views of teaching and learning to promote 21st century skills and global perspectives. Education Research and Perspectives, 40: 86108. 
Starkey L (2011). Evaluating learning in the 21st century: a digital age learning matrix. Technology, Pedagogy and Education, 20(1): 19-39.

TCT (2013). Teacher profession standards. Teacher Council of Thailand. (In Thai), Available online at: http://www.ksp.or.th/ ksp2013/content/view.php?mid=136anddid=254.
Williams MK, Foulger TS, and Wetzel K (2009). Preparing preservice teachers for 21st century classrooms: Transforming attitudes and behaviors about innovative technology. Journal of Technology and Teacher Education, 17(3): 393-418. 